\title{
Plutarch w Semeioseis gnomikai Teodora Metochitesa
}

\author{
Katarzyna JAŻDŻEWSKA*
}

\begin{abstract}
Plutarch in Semeioseis gnomikai of Theodore Metochites: The paper focuses on the reception of Plutarch's Moralia in Theodore Metochites' Semeioseis gnomikai. It discusses chapter 71 of Metochites' work, one of several chapters focused on ancient authors, which is dedicated to Plutarch. Metochites praises Plutarch as a wise man and a philosopher and in particular approves of his character. According to Metochites, Plutarch was not tainted by the usual flaws of intellectuals such as envy and arrogance, but was motivated by a pure love of wisdom and generously acknowledged the achievements of his predecessors. Metochites interprets Plutarch's erudition, polymathia, as a sign of a noble, high-minded nature, and therefore as evidence of moral virtue.
\end{abstract}

KEYWORDS

Plutarch; Theodore Metochites; reception; Byzantium

* Dr, adiunkt w Instytucie Filologii Klasycznej i Kulturoznawstwa, Uniwersytet Kardynała Stefana Wyszyńskiegow Warszawie. E-mail: kjazdzewska@gmail.com. 
[Plutarch] ist ein Stück von uns, und das ehrliche Streben, uns selbst zu kennen, muß uns immer wieder zu ihm zurückführen.

(Hirzel, 1912: 205)

Dzieje recepcji tekstów starożytnych odzwierciedlają zarówno indywidualne zainteresowania czytelników, jak i trendy intelektualne ich czasów. Nie inaczej jest w przypadku recepcji Plutarcha. Historia interakcji kultury i literatury europejskiej z jego twórczością jest niezwykle barwna i pouczająca: pisma Plutarcha stanowiły inspirację dla autorów tak różnych, jak Erazm z Rotterdamu, Michel de Montaigne, William Shakespeare, Francis Bacon, Jean-Jacques Rousseau, rewolucjoniści francuscy czy Friedrich Schiller ${ }^{1}$; każdy z nich miał swój obraz pisarza, ukształtowany przez własne zainteresowania i temperament oraz ducha czasów. Pisma Plutarcha, które biły rekordy popularności w jednych okresach, schodziły w cień w innych; uznanie dla pedagogicznych porad i koncepcji wychowania ustępowało przed zainteresowaniem historycznymi anegdotami, politycznymi poradami czy zaleceniami moralnymi.

Niniejsze studium wiedzie do czternastowiecznego Konstantynopola i jest próbą zrozumienia fascynacji Plutarchem Teodora Metochitesa - polityka, pisarza, filozofa, poety $(1270-1332)^{2}$. Jego intensywne i burzliwe życie przypada na okres renesansu Paleologów, następujący po odbiciu Konstantynopola z rąk krzyżowców w 1261 roku. Czas ten charakteryzował się niezwykłym rozkwitem literatury i sztuki, a w szczególności wzmożonym zainteresowaniem dziedzictwem antycznym (Fryde, 2000). Dla recepcji Plutarcha jest to okres szczególnie ważny. Powstaje wtedy kluczowe wydanie rozproszonych dotąd Moraliów. Jego autorem jest Maximos Planudes (ok. 1255-1305), który, jak wyznaje w liście do przyjaciela, Plutarcha szczególnie umiłował ${ }^{3}$. Planudes był związany z klasztorem Chora i tam też pracował nad wydaniem dzieł greckiego pisarza; możemy przypuszczać, że nieco młodszy od Planudesa Teodor Metochites, który otoczył ten klasztor szczególną opieką i regularnie uzupełniał jego bibliotekę, korzystał z jego wydania (Ševčenko, 1975; Tartaglia, 1987).

$\mathrm{Na}$ obfitą spuściznę literacką Metochitesa składają się rozmaite pisma astronomiczne, filozoficzne, utwory poetyckie oraz mowy. Tekst Semeioseis gnomikai $(S G)^{4}$, który stanowi temat niniejszego studium, nie daje się zakwalifikować

${ }^{1}$ Zob. zarys recepcji Plutarcha od starożytności do początku XX wieku w Hirzel, 1912: 74-206. Praca Marianne Pade (Pade, 2007) dotyczy recepcji Żywotów Plutarcha we Włoszech w XV wieku, ale we wstępnym rozdziale omówiona jest recepcja jego twórczości od starożytności do XIII wieku. Na temat recepcji Plutarcha u Focjusza, zob. Schamp, 1996.

${ }^{2} \mathrm{Na}$ temat życia i twórczości Metochitesa zob. Beck, 1952; Hunger, 1952; Ševčenko, 1975; zob. też Ševčenko, 1974 na temat życia intelektualnego Bizancjum w XIV wieku.

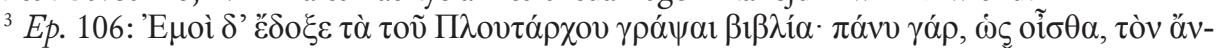
$\delta \rho \alpha \varphi \imath \lambda \tilde{\omega}$. Na temat Planudesa i jego pracy nad wydaniem Plutarcha, zob. np. Ševčenko, 1974.

${ }^{4}$ Karin Hult określa datę publikacji tekstu na lata 1321-1328 (Hult, 2002: XIV). Zwyczajowy tytuł łaciński $S G$ to Miscellanea philosophica et bistorica. Pełne wydanie $S G$ w Müller 
do żadnej z tych kategorii. Jest to zbiór stu dwudziestu rozdziałów różniących się pod względem długości oraz treści, porównywany czasem do Prób Montaigne'a czy Adagiów Erazma z Rotterdamu (Featherstone, 2011: 335). W pierwszym rozdziale Metochites z zadumą zauważa, że wieki intensywnej działalności pisarskiej poprzedzające jego czasy nie zostawiły jego współczesnym nic nowego do powiedzenia: pozostaje im jedynie milczenie bądź też powtarzanie tego, co już zostało powiedziane. Metochites milczeć nie zamierzał, czego dowodzi ponad sto rozdziałów następujących po przedmowie, w których autor zastanawia się między innymi nad działalnością intelektualną, przedstawia swoją ocenę pisarzy starożytnych, omawia różne dziedziny wiedzy i ustroje polityczne, rozważa kwestie ludzkiego losu, natury ludzkiej, przeszłości, historii, wiary chrześcijańskiej, miłości własnej, właściwego stosunku do dóbr materialnych i udziału w życiu politycznym. W doborze tematów w $S G$ dostrzec można wpływ Plutarcha. Epaminondas i Pelopidas, dwaj dowódcy beoccy, którym Metochites poświęca rozdział 114, byli ważnymi postaciami dla pochodzącego z beockiej Cheronei Plutarcha, który skomponowat ich biografie; obaj też pojawiają się w De genio Socratis ${ }^{5}$. Refleksje Metochitesa o epikurejskiej maksymie $\lambda \dot{\alpha} \theta \varepsilon \beta 1 \omega ́ \sigma \alpha \varsigma \mathrm{w}$ rozdziale 72 być może są zainspirowane tekstem Plutarcha An recte dictum sit latenter esse vivendum. Seria rozdziałów poświęconych przez Metochitesa kwestii dóbr materialnych (82-86) ma swój odpowiednik w Plutarchowym O pragnieniu bogactwa (De cupiditate divitiarum). Tekst Plutarcha Jak można chwalić siebie samego, nie budząc niechęci (De laude ipsius), w którym wielokrotnie powtarza się słowo $\pi \varepsilon \rho 1 \alpha v \tau o \lambda o \gamma i \alpha$, zapewne był inspiracją dla roz-

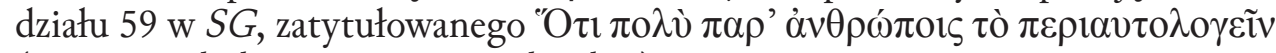
(O tym, że ludzie często sie przechwalaja).

Różnorodność tematyczna zbioru, luźna struktura tekstu, w którym Metochites wydaje się kierować raczej tropem swoich skojarzeń niż ustalonym uprzednio planem, oraz osobisty charakter refleksji sprawiają, że forma i charakter tekstu nie mają precedensu w zachowanej literaturze greckiej. Niektórzy badacze Metochitesa widzą podobieństwo między strukturą $S G$ a Plutarchowymi Moraliami ${ }^{6}$. Jest prawdopodobne, że zebrane przez Planudesa w różnorodny corpus rozproszone uprzednio Moralia w rzeczy samej zainspirowały Metochitesa, tak jak nieco później wywarły wpływ na kształt Prób Montaigne’a (na temat obecności Plutarcha w dziele Montaigne'a, zob. Konstantinovic, 1989;

\& Kiessling, 1821. Edycja Hult, 2002 obejmuje rozdziały 1-26 i 71, które zostały opatrzone angielskim przekładem.

${ }^{5}$ Biografia Epaminondasa, która stanowiła parę z żywotem Scypiona, nie zachowała się. Na temat przedstawienia Epaminondasa i Pelopidasa w De genio Socratis, zob. np. Pelling, 2010.

${ }^{6}$ Herbert Hunger nazywa $S G$,ein Pendant zu den plutarchischen Moralia” (Hunger, 1952: 9). Börje Bydén wymienia wśród autorów, których pisma mogły stanowić dla Metochitesa inspirację, Plutarcha, Eliana, Klemensa Aleksandryjskiego i Maximosa z Tyru (Bydén, 2002: 248-249). 
Smith, 2001). Jednak różnice między SG a Moraliami są zasadnicze. Plutarchowe Moralia stanowią konglomerat niezależnych, zróżnicowanych pod względem formy tekstów (dialogi, mowy, traktaty, konsolacje itd.), często skierowanych do określonych adresatów. Rozdziały $S G$ stanowią jednolite formalnie elementy większej całości, chociaż jedynie luźno ze sobą powiązane. Metochites nie zwraca się do konkretnego adresata, często natomiast posługuje się pierwszą osobą, co nadaje $S G$ charakter osobistych refleksji.

Poświęcony w całości Plutarchowi rozdział $71 S G$ jest jednym z szeregu rozdziałów, które Metochites dedykuje autorom starożytnym ${ }^{7}$. Oprócz Plutarcha omawia on w niezależnych rozdziałach Józefa Flawiusza ( $S G 15)$, Filona z Aleksandrii ( $S G$ 16), Synezjusza ( $S G 18$ ), Diona Chryzostoma ( $S G$ 19) oraz Ksenofonta ( $S G 20)$, a zatem głównie autorów okresu cesarstwa. Metochites nie wyjaśnia, dlaczego skupia swoją uwagę na tych właśnie pisarzach; nie zachowuje również porządku chronologicznego, lecz raczej porządek skojarzeniowy ${ }^{8}$, co wpisuje się w „eseistyczny” czy „zapiskowy” charakter $S G$. Poza tym w kilku rozdziałach Metochites omawia charakter, sławę i w mniejszym stopniu twórczość Platona, Arystotelesa oraz Pitagorasa (rozdziały 3, 5, 7, 8, 10-13, 21, 24-25).

Dotyczący Plutarcha rozdział 71 badacze uważają za powiązany z segmentem rozdziałów poświęconych pozostałym autorom starożytnym (SG 15-20); niektórzy wysuwają hipotezę, że został on oddzielony od nich dopiero w ostatecznej redakcji'. Trzeba jednak zauważyć, że ma on nieco inny charakter od rozdziałów 15-16 i 18-20, które skupione są przede wszystkim na kwestii stylu omawianych pisarzy ${ }^{10}$. Rozdział dotyczący Plutarcha jest od nich znacznie dłuższy $^{11}$; ponadto Metochites poświęca zagadnieniu stylu filozofa zaledwie jedną czwartą rozdziału, skupiając się głównie na pochwale charakteru i erudycji pisarza oraz wszechstronności jego pism. Również pozycja rozdziału $71 \mathrm{w}$ „sieci skojarzeń” Metochitesa jest dobrze ugruntowana: w rozdziale wcześniejszym

${ }^{7}$ Wszystkie cytaty z $S G$ oraz numeracja rozdziałów pochodzą z edycji Hult, 2002.

${ }^{8}$ Istnieje związek skojarzeniowy pomiędzy rozdziałami poświęconymi poszczególnym autorom: Józef i Filon, których zainteresowania i styl Metochites porównuje w rozdziale 16 (119-120), obaj byli Żydami; rozdział 17, który dotyczy stylu pisarzy wykształconych w Aleksandrii, stanowi ogniwo łączące rozważania Metochitesa na temat stylu Filona w rozdziale 16 i stylu Synezjusza w rozdziale 18; po rozdziale dotyczącym Synezjusza Metochites omawia Diona Chryzostoma, któremu Synezjusz poświęcił jeden ze swoich tekstów, a następnie Ksenofonta, którego pisma rekomendował Dion w mowie 18.

${ }^{9}$ Wydanie Hult obejmuje rozdziały 1-26 i 71; jak wyjaśnia autorka, rozdział dotyczący Plutarcha należy tematycznie do grupy rozdziałów 15-20 (Hult, 2002: XLI). Michael J. Featherstone bierze pod uwagę, chociaż bez przekonania, koncepcję innego układu w pierwotnej wersji tekstu (Featherstone, 2011: 342).

${ }^{10} \mathrm{Na}$ temat koncepcji stylu Metochitesa oraz używanej przez niego, opartej na Hermogenesie terminologii, zob. Bydén, 2002: 273-283; Hult, 2004.

${ }^{11}$ Rozdział 71 liczy w wydaniu Hult 12 stron tekstu greckiego, podczas gdy rozdział dotyczący Józefa Flawiusza - 2,5 strony, Filona - 4 strony, Synezjusza -5 stron, Diona Chryzostoma - 4,5 strony, Ksenofonta - 3 strony. 
(SG 70) Metochites wspomina Plutarcha, a rozdział następny (SG 72) zainspi-

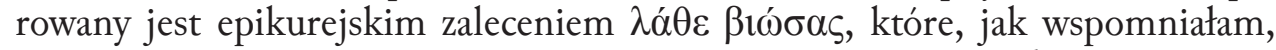
jest przedmiotem ataku jednego z tekstów należących do Moraliów.

Idealizująca pochwała Plutarcha, jaką stanowi rozdział 71, ukazuje go jako niedościgniony wzór uczonego, filozofa i mędrca. W zdaniach otwierających rozdział Metochites uprzedza ewentualne zarzuty czytelników dotyczące doboru materiału, twierdząc, że charakter $S G$ pozwala mu swobodnie decydować, co uwzględnia w swoim tekście, i nie nakłada na niego żadnych gatunkowych zobowiązań $(S G 71.1 .2-3)^{12}$. Rozdział 71 nie jest zatem próbą całościowego przedstawienia dzieła Plutarcha, lecz raczej szkicem selektywnie ukazującym pewne aspekty jego charakteru, myśli i twórczości.

Treści pism Plutarcha Metochites poświęca zaskakująco niewiele uwagi ${ }^{13}$. Jedyny tekst wymieniony z tytułu to uznany dziś za nieautentyczny traktat

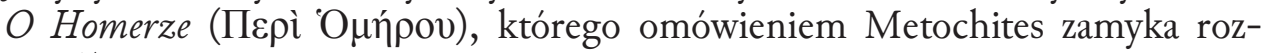
dziaf $^{14}$. Ponadto autor stwierdza, że większość pism Plutarcha dotyczy kwestii etycznych i politycznych ( $S G$ 71.3.2), wspomina jego krytyczne stanowisko wobec stoików i epikurejczyków ( $S G 71.3 .4-5,71.5-6)$ oraz pisze, że Plutarch stworzył „kilka pism na tematy przyrodnicze” (SG 71.3.6). Różnorodność tematyki tekstów Plutarcha podsumowuje Metochites stwierdzeniem, że zebrał on wszystko, co wydarzyło się w przeszłości wśród Greków, Rzymian i wszystkich innych ludów, i przedstawił bieg spraw ludzkich od samego początku. Rozbudowane wyliczenie tematów poruszanych przez Plutarcha ma uzmystowić czytelnikowi wszechstronność jego zainteresowań i nieprzebrane bogactwo wiedzy: Plutarch przedstawił w swoich dziełach historię mniejszych i większych państw, różne ustroje polityczne, rozmaite zwyczaje i style życia, wynalezienie sztuk i ich praktykowanie, migracje ludności i kolonizacje, wojny i działania militarne, początki wszelkiej wiedzy, wynalazców oraz mistrzów wszystkich dyscyplin składających się na wykształcenie, różne szkoły filozoficzne i różnice między nimi ( $S G$ 71.8.1-3). Teksty Plutarcha stanowią zatem dla Metochitesa przede wszystkim niezwykle cenne repozytorium wiedzy, głównie faktów z zakresu historii politycznej i historii kultury; niewiele uwagi natomiast poświęca Metochites w rozdziale 71 jego myśli filozoficznej czy też zaleceniom etycznym.

Bardziej niż styl Plutarcha czy treść poszczególnych jego pism interesuje Metochitesa osobowość pisarza, której emanacją są dla niego jego dzieła. Zainteresowanie charakterem omawianych autorów jest obecne również $\mathrm{w}$ innych

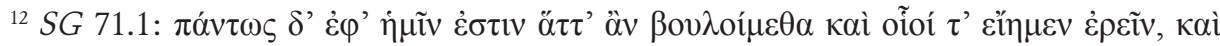

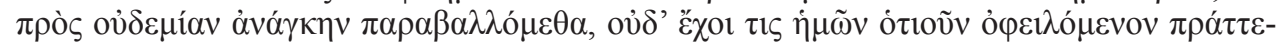

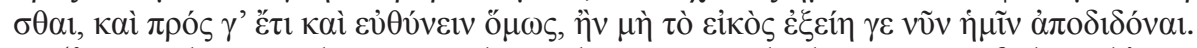

${ }^{13}$ Stwierdzenie Hult, że Metochites "discusses mostly the contents of Plutarch's writings" (Hult, 2004: 49), nie jest zatem, ściśle rzecz biorąc, słuszne.

${ }^{14}$ Por. np. z rozdziałem 3, w którym Metochites, omawiając Arystotelesa, wymienia szereg tytułów jego pism. 
rozdziałach $S G$, szczególnie w tych, których przedmiotem jest Arystoteles, z którym Metochites, autor komentarzy do jego pism, był dobrze obeznany. O ile jednak Arystoteles stanowi dla Metochitesa uosobienie przywar typowych dla filozofów, takich jak pycha i zawiść, o tyle Plutarch jest przykładem autora, który jest ich całkowicie pozbawiony.

Począwszy od pierwszego zdania rozdziału 71, Metochites podkreśla niezwy-

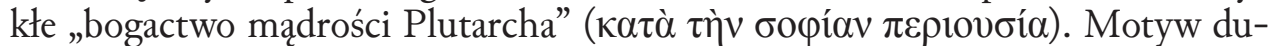
chowego bogactwa, nawiązujący do etymologii imienia Plutarcha (Plout-archos), przewija się w tekście wielokrotnie: Metochites używa określeń $\pi \lambda$ oṽ $\tau$ ऽ — „bo-

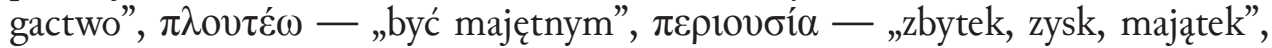

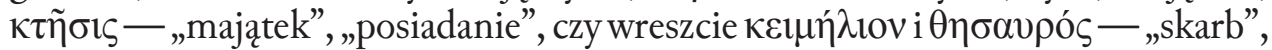
„skarbiec”. „Bogactwo” Plutarcha przejawia się w ogromie i różnorodności wiedzy, jaką zawierają jego pisma, i jest w pierwszej kolejności rezultatem talentu, jakim obdarzyła go natura ${ }^{15}$. Według Metochitesa, większość ludzi wykazuje naturalne zdolności albo $\mathrm{w}$ stosunku do dziedzin wyższych ( $\tau \grave{\alpha} \pi \lambda \varepsilon i ́ \omega \pi \varepsilon \varphi v ́ \kappa \alpha-$

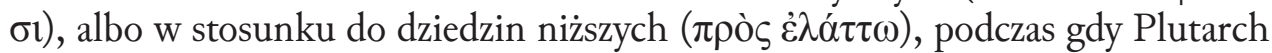

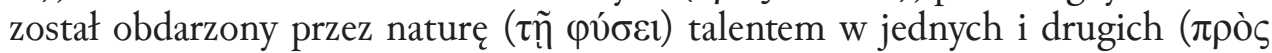

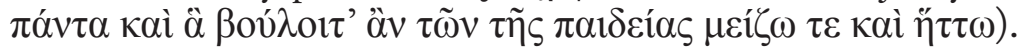

Metochites wyróżnia też drugi, obok naturalnych zdolności, czynnik, który wpłynął na kształt spuścizny Plutarcha, a mianowicie „miłość do rzeczy naj-

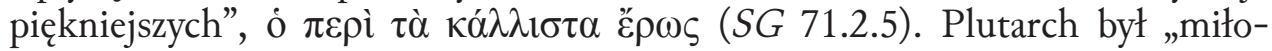

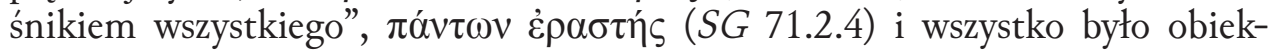

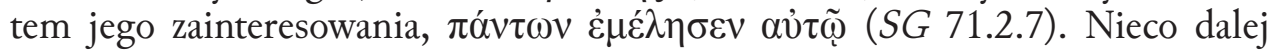
Metochites podkreśla, że w odniesieniu do filozofii Plutarch dokładał starań, by „wszystko wiedzieć i nie wykazywać niewiedzy w odniesieniu do niczego”, a jego ambicją było poznać i zapamiętać wszystko, co kiedykolwiek zostało napisane (SG 71.4.1-2), oraz że nie było nigdy człowieka, któremu zależałoby bardziej niż Plutarchowi, by „wiedzieć wszystko, co się zdarzyło przed nim wśród Greków, Rzymian i wszystkich ludzi” (SG 71.8.1).

W tym obrazie Plutarcha i jego żarliwego pragnienia pozyskania wszelkiego poznania możemy zauważyć inspiracje platońskie. W SG 71.2.4 Metochites pisze, że Plutarch był nienasycony i zachłanny w swoim dążeniu do wiedzy (oủ $\delta \dot{\varepsilon} v$

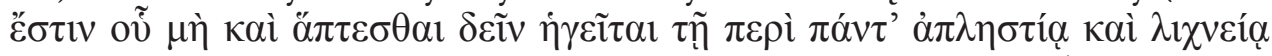

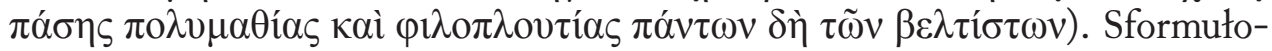
wanie to nawiązuje do fragmentu Państwa, w którym Sokrates rozważa naturę filozofa $(475 b-c)$ :

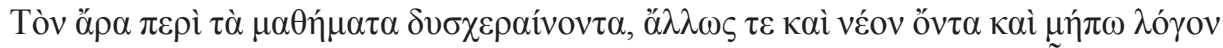

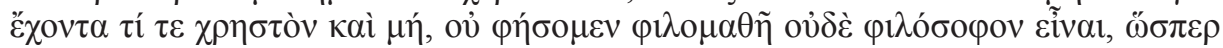

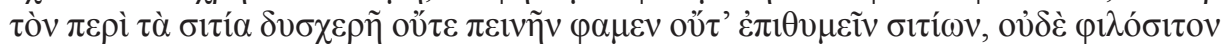

${ }^{15}$ Pojęcie naturalności stylu jest nacechowane szczególnie pozytywnie w $S G$, jak zauważa Hult, 2004: 54-55. 


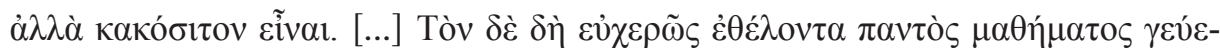

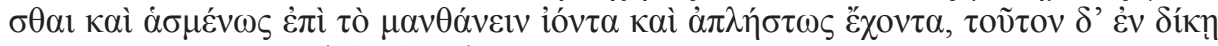

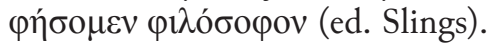

Więc kto się nie lubi uczyć, zwłaszcza kiedy jest młody i jeszcze nie ma tego rozeznania, co się przyda na coś, a co nie, o tym nie powiemy, że to miłośnik uczenia się ani miłośnik mądrości; zupełnie tak, jak o tym, któremu pokarmy nie smakują, nie powiemy, że łaknie ani że pożąa pokarmów, ani że lubi jeść, tylko to, że ma jadłowstręt [...] A tego, który się garnie i pragnie kosztować wszelkich przedmiotów nauki, i z radością idzie się uczyć, i nigdy nie ma dość, tego słusznie nazwiemy miłośnikiem mądrości, filozofem (przet. W. Witwicki).

Plutarch Metochitesa, jak platoński filozof, jest nienasycony ( $\dot{\alpha} \lambda \lambda \dot{\sigma} \sigma \tau \omega \varsigma$

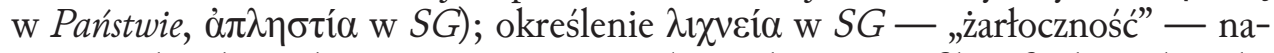
wiązuje do platońskiego porównania osoby o dyspozycji filozofa do miłośnika jedzenia. Plutarcha $\pi \circ \lambda \nu \mu \alpha \theta i ́ \alpha$ i $\varphi \imath \lambda o \mu \alpha \theta i ́ \alpha$, umiłowanie wiedzy i wszechstronna uczoność, są zatem świadectwami jego prawdziwie filozoficznego usposobienia ${ }^{16}$.

Określając miejsce filozofii w życiu i twórczości Plutarcha, Metochites stwierdza, że nadawała ona kierunek jego życiu i kształtowała jego pisma

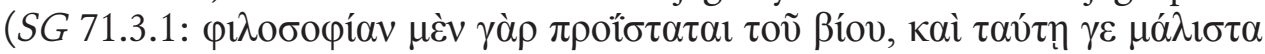

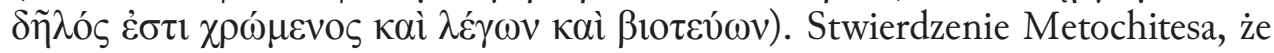
Plutarch, w odróżnieniu od współczesnych sobie filozofów, nie był zwolennikiem żadnej określonej szkoły filozoficznej — platońskiej, arystotelejskiej czy innej ( $S G$ 71.4.4) - jakkolwiek nieodzwierciedlające rzeczywistego stanu rzeczy, pozostaje spójne z wizerunkiem pisarza, jaki tworzy Metochites: Plutarch, osądzając poglądy różnych szkół filozoficznych, kierował się według Metochitesa jedynie pragnieniem poznania i bezstronnością. Porównanie Plutarcha do bez-

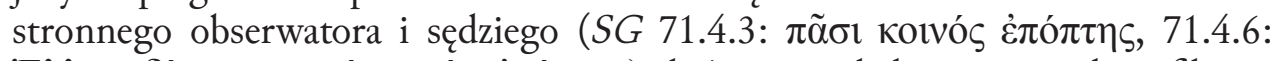

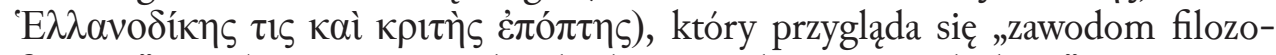
ficznym” oraz biorącym w nich udziat „zapaśnikom i zawodnikom”, jest nawiązaniem do przypisywanej Pitagorasowi metafory, wedle której życie jest niczym dzień świąteczny, w czasie którego niektórzy ludzie startują w zawodach, niektórzy handlują, a inni - ci najlepsi - są widzami; podobnie w życiu, niektórzy są niewolnikami sławy, inni dążą do zysku, filozofowie zaś poszukują prawdy (Cicero Tusculanae disputationes 5.8; Diogenes Laertios VIII 8) ${ }^{17}$. Metochites przeformułowuje tę metaforę przez wprowadzenie dodatkowej kategorii — bezstronnego sędziego-eksperta, który reprezentuje Plutarcha - oraz czyniąc zawody atletyczne metaforą obrazującą rywalizację pomiędzy przedstawicielami poszczególnych szkół filozoficznych.

${ }^{16}$ Określenie $\pi \mathrm{o} \lambda v \mu \alpha \theta i ́ \alpha$ występuje w $S G 71$ pięć razy; $\varphi \imath \lambda \mathrm{\imath} \mu \mu \alpha \theta \dot{\varepsilon} \varsigma$ - jeden raz. W $S G$ 71.12.7 Plutarch jest określony jako $\pi$ o $\lambda v \mu \alpha \theta \varepsilon \dot{\sigma} \tau \alpha \tau o \varsigma$ (por. też $S G 3.1 .3$ ).

${ }^{17}$ Anegdota pochodzi z niezachowanego dialogu Heraklejdesa z Pontu, zob. Gottschalk, 1980: 23-33. 
Wszechstronność, erudycja, obfitość nawiązań do wcześniejszych autorów, wreszcie eklektyzm filozoficzny Plutarcha stanowią dla Metochitesa przejawy szlachetności Cheronejczyka, który uznaje zasługi swych poprzedników bez umniejszania ich. Metochites charakteryzuje Plutarcha jako człowieka skrom-

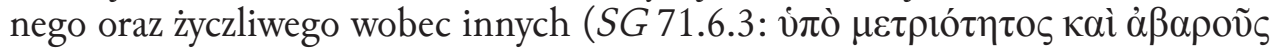

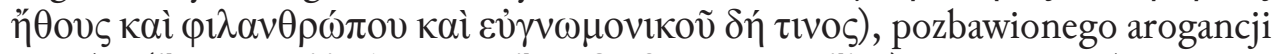

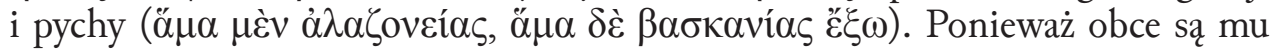

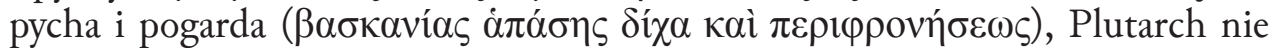
cofa się przed przytaczaniem, poza wydarzeniami uświęconymi przez historię, również wydarzeń współczesnych oraz wypowiedzi mało znaczących, którymi inni gardzą (SG 71.7.3-6). Ta niewybredność Plutarcha jest przejawem jego

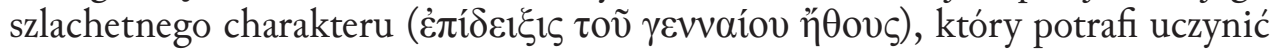
pożytek z wszystkiego.

Rozdział 71 nie jest jedynym fragmentem $S G$, w którym Metochites rekonstruuje osobowość autora starożytnego na podstawie charakteru jego pism. Szczególnie instruktywne jest porównanie pochwały Plutarcha z krytyką Arystotelesa, której Metochites dokonuje w kilku pierwszych rozdziałach $S G$. Metochites niejednokrotnie podkreśla swoje uznanie dla osiągnięć Arystotelesa, szczególnie w zakresie logiki i nauk przyrodniczych: rozdział 5 otwiera pochwała filozofa, którego dzieła Metochites uważa za najważniejsze osiągnięcie ludzkie w dziedzinie mądrości ${ }^{18}$. Jednocześnie stwierdza on, że Arystoteles był człowiekiem niezwykle próżnym. W rozdziale 3 , który poświęcony jest niejasności Arystotelesa, twierdzi, że filozof ten używa niejasnych sformułowań umyślnie, aby wydawać się mądrzejszym, niż jest w istocie; kieruje nim zatem niechlubne

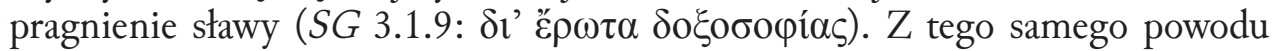
według Metochitesa Arystoteles bezlitośnie krytykuje wszystkich swoich poprzedników oraz nie uznaje zasług Platona, swojego „przewodnika w mądrości”, starając się ukryć swoją zależność od niego poprzez używanie innego słownictwa filozoficznego ( $S G$ 3.2.3). W rozdziale 3 i 5 napotykamy metaforę skarbca, którą, jak widzieliśmy, Metochites chętnie posługuje się, pisząc o Plutarchu. $\mathrm{O}$ ile jednak Plutarch w istocie jest niczym skarbiec, o tyle Arystoteles jedynie

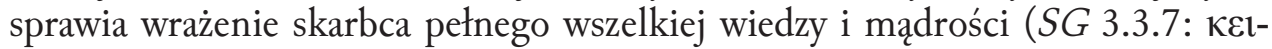
$\mu \eta ́ \lambda ı \alpha, 5.2 .2:$ : $\eta \sigma \alpha v \rho o ́ \varsigma)$. To wrażenie jest skutkiem zabiegów samego Arystotelesa, który niejednokrotnie sugeruje, że wie więcej, niż przekazuje, i że część swojej wiedzy zachowuje dla siebie ( $S G 5.2 .2-3)$.

Arystoteles nie jest zresztą odosobniony w swojej słabości: w rozdziale 4 Metochites stwierdza, że wszyscy pisarze i filozofowie pragną wydawać się

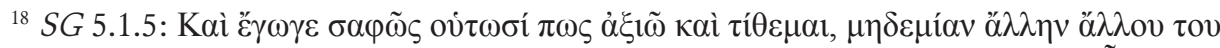

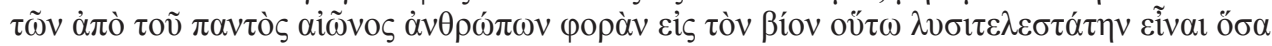

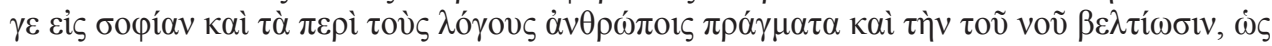

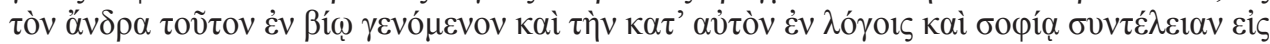

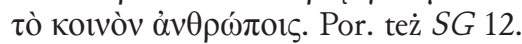


mądrzejsi niż są w rzeczywistości i w związku z tym wyolbrzymiają swoje zasługi, nie cofając się przed kłamstwem, zniekształcaniem rzeczywistości czy przywłaszczaniem sobie cudzych osiągnięć; co więcej, pod wpływem miłości własnej zaczynają wierzyć w tworzony przez siebie obraz własnej osoby ${ }^{19}$. Jako przykłady postaci dotkniętych tą słabością wymienia Metochites Sokratesa, Diogenesa, Antystenesa i Kratesa oraz, w szczególności, Platona, który w swoich tekstach krytykuje bezlitośnie swoich poprzedników i pragnie zagarnąć dla siebie całość

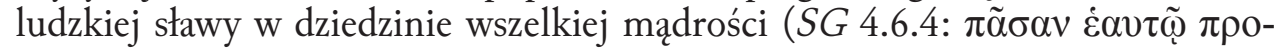

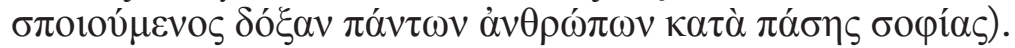

W kontekście rozdziałów 3-5, które piętnują próżność jako uniwersalną przywarę wszystkich pisarzy i myślicieli, Plutarch, czy raczej Metochitesa konstrukcja osobowości Plutarcha, stanowi przypadek wyjątkowy. Pozbawiony próżności, zawiści i pogardy, szanujący poprzedników i uznający ich osiągnięcia, motywowany czystym pragnieniem wiedzy, bezstronnie oceniający współczesne sobie spory filozoficzne - Plutarch Metochitesa wznosi się ponad naturalne ograniczenia ludzkiej natury.

Jedynym tekstem Cheronejczyka, który Metochites decyduje się omówić

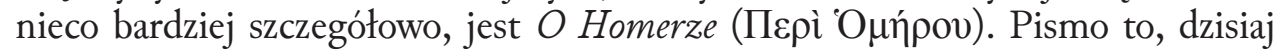
uważane za nieautentyczne, zostało włączone do zbioru dzieł Plutarcha przez Planudesa, z którego wydania Metochites zapewne korzystał ${ }^{20}$. Metochites zamyka rozdział poświęcony Plutarchowi omówieniem i pochwałą tego właśnie pisma, ponieważ doskonale potwierdza ono jego argument o wszechstronności Cheronejczyka i jego wielkodusznej szlachetności przejawiającej się w uznaniu zasług poprzedników. Autor O Homerze argumentuje, że Iliada i Odyseja stanowią źródło oraz inspirację wszelkiej późniejszej wiedzy w całej jej różnorodności: fizyki, nauki o duszy, etyki, pitagorejskiej nauki o liczbach, retoryki, prawa, filozofii politycznej, taktyki czy nawet medycyny. Tekst ten zatem przedstawia Homera

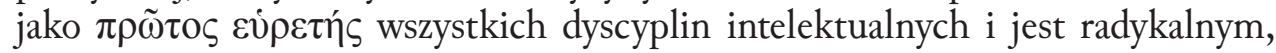
choć nieco groteskowym wcieleniem w życie owej badawczej wielkoduszności, którą Metochites pochwala w $S G$ : Plutarch, jak Metochites podkreśla, oddaje

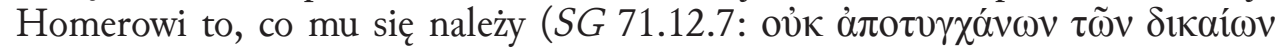

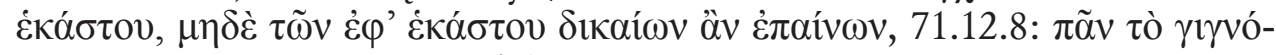

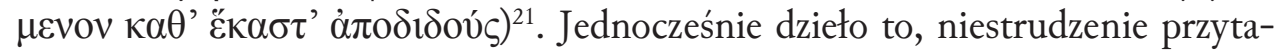
czające homerycki cytat za cytatem w celu wykazania, że każda z omawianych dziedzin wiedzy ma swoje źródło w wersach poety, przejawia niewątpliwie charakter encyklopedyczny i erudycyjny: jego autor wykazuje się zarówno dogłębną

\footnotetext{
${ }^{19}$ Por. też rozdział $S G 52$, którego tematem jest miłość własna.

${ }^{20} \mathrm{Na}$ temat pseudo-plutarchowego tekstu $O$ Homerze i jego transmisji, zob. Kindstrand, 1990: V-LXI oraz przedmowa w wydaniu Keaney \& Lamberton, 1996: 1-30.

${ }^{21}$ Jak zauważa Lawrence Kim, autor $O$ Homerze przedstawia poetę ,as a disembodied force of nature, a mystical and arcane symbolist, or a semi-divine creator of complex didactic allegorical narratives" (Kim, 2010: 12).
} 
znajomością poematów Homera, jak i poszczególnych nauk. Ukazując Homera

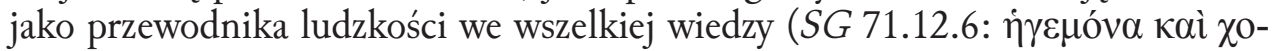

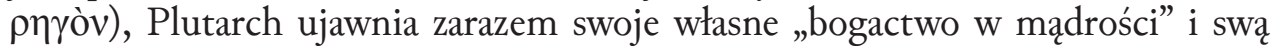

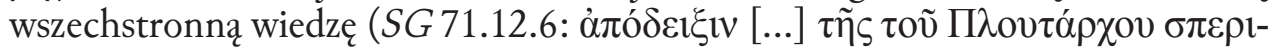

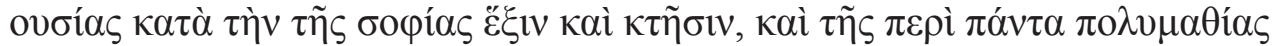

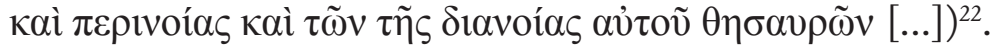

Idealizująca pochwała Plutarcha w $S G 71$ jest więc przede wszystkim pochwałą erudycji i encyklopedyzmu, które w przekonaniu Metochitesa są rezultatem niepospolitych zdolności oraz szlachetności charakteru. Пo $\lambda v \mu \alpha \theta i ́ \alpha$ jest przejawem cnoty moralnej, a zatem owocem prawdziwie filozoficznego życia. Metochites zatem występuje przeciw tym, którzy przeciwstawiali wiedzę mą-

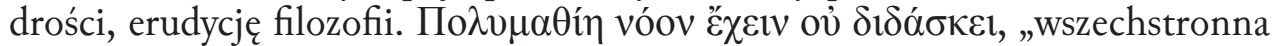
wiedza nie przynosi mądrości”, miał rzec Heraklit² ${ }^{23}$. W Memorabiliach Ksenofonta Sokrates, zaczepiony przez Hippiasza, przyznaje, że wciąż rozprawia o tych samych sprawach, po czym dodaje: „ty zaś dzięki swojej erudycji ( $\delta i \grave{\alpha} \tau o ̀ ~ \pi o \lambda v-$ $\mu \alpha \theta \grave{n} \varsigma$ Eĩval) nigdy nie mówisz tego samego o tych samych sprawach!" (Memorabilia 4.4.6). W cytowanym powyżej fragmencie Państwa (475b-c) Sokrates wydaje się zalecać zdobywanie wszechstronnej wiedzy poprzez „kosztowanie wszelkich przedmiotów nauki”, jednak z pewnym ograniczeniem - taka „dieta" jest dobra dla tego, kto jest młody i nie ma rozeznania, co jest przydatne, a co nie. Platońskie Prawa odradzają wszechstronne kształcenie i uważają je za potencjalnie niebezpieczne ${ }^{24}$; pseudoplatoński dialog Amatores odrzuca twierdzenie, że $\pi \mathrm{o} \lambda v \mu \alpha \theta$ í $\alpha$ jest drogą prowadzącą do filozofii lub sposobem jej uprawiania. Wbrew tego typu postawom pochwała Plutarcha w $S G$ jest apologią i afirmacją erudycji, która według Metochitesa rodzi się tam, gdzie spotykają się wiedza, filozofia i szlachetność charakteru.

\section{ZASADY PRZYWOŁYWANIA TEKSTÓW ŹRÓDŁOWYCH}

Numeryczne odwołania do tekstów Plutarcha odwołują się do standardowej paginacji stosowanej w naukowych edycjach Moraliów. Analogicznie, numeryczne odwołania w odniesieniach do Platona - za ogólnie wykorzystywaną w wydaniach naukowych paginacją Stephanusa. Odniesienia do dzieł Ksenofonta, Diogenesa Laertiosa oraz presokratyków również za kanonicznym podziałem relewantnych tekstów przyjętym w edycjach krytycznych (księga, rozdział, paragraf) wedle bazy danych Thesaurus Linguae Graecae ${ }^{\circledR}$ Digital Library. (Ed. M. C. Pantelia).

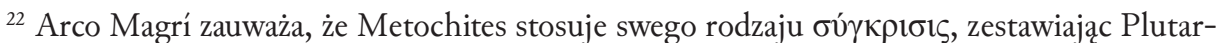
cha z Homerem; porównanie to ukazuje, że Plutarch i Homer stanowią „identiche espressioni della бọía” (Arco Magrí, 1991: 466)

${ }^{23}$ Diels-Kranz B 40.

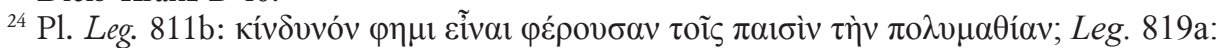

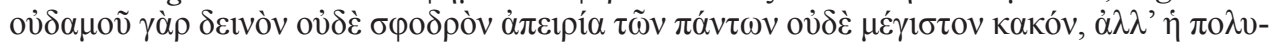

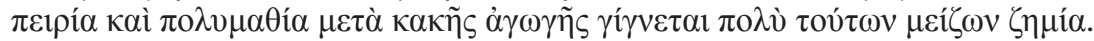


Irvine: University of California. Dostęp: http://www.tlg.uci.edu (28.12.2017). Odniesienia do Metochitesa wedle podziałów wewnętrznych zaproponowanych w cytowanym wydaniu (Hult, 2002). Odniesienia do Cycerona wg wydania M. Tulli Ciceronis Tusculanorum disputationum libri quinque. A revised text with introduction and commentary of T. W. Dougan. Cambridge: Cambridge University Press 1934.

\section{BIBLIOGRAFIA}

Arco Magrí, M. (1991). Una pagina di Metochite sul ПEPI OMHPO di Plutarco (s. 461-473). W: G. D’Ippolito, I. Gallo (Red.). Strutture formali dei Moralia di Plutarco. Atti del III Convegno Plutarcheo, Palermo 3-5 maggio 1989. Napoli: M. D’Auria Editore.

Beck, H.-G. (1952). Theodoros Metocbites. Die Krise des byzantinischen Weltbildes im 14. Jabrbundert. München: C.H. Beck.

Bydén, B. (2002). The nature and purpose of the 'Semeioseis gnomikai': The antithesis of philosophy and rhetoric (s. 245-288). W: K. Hult (Red.). Theodore Metochites on ancient authors and philosophy. 'Semeioseis gnomikai' 1-26 \& 71. Göteborg: Acta Universitatis Gothoburgensis.

Featherstone, M. J. (2011). Theodore Metochites's 'Semeioseis gnomikai': Personal encyclopedism (s. 333-344). W: P. Van Deun \& C. Macé (Red.). Encyclopedic trends in Byzantium? Proceedings of the International Conference held in Leuven, 6-8 May 2009. Leuven: Peeters.

Fryde, E. (2000). The early Palaeologan Renaissance (1261-c. 1360). Leiden: Brill.

Gottschalk, H. B. (1980). Heraclides of Pontus. Oxford: Oxford Clarendon Press.

Hirzel, R. (1912). Plutarch. Leipzig: Theodor Weicher.

Hult, K. (2002). Theodore Metochites on ancient authors and filosophy: 'Semeioseis gnomikai' 1-26 \& 71. Göteborg: Acta Universitatis Gothoburgensis.

Hult, K. (2004). Theodore Metochites as a literary critic (s. 44-56). W: J. O. Rosenqvist (Red.). Interaction and isolation in late Byzantine culture. Stockholm: I.B. Tauris.

Hunger, H. (1952). Theodoros Metochites als Vorläufer des Humanismus in Byzanz. Byzantinische Zeitschrift, 45, 4-19.

Keaney, J. J. \& Lamberton, R. (Red.). (1996). [Plutarch] Essay on the life and poetry of Homer. Atlanta: American Philological Association.

Kim, L. (2010). Homer between bistory and fiction in imperial Greek literature. Cambridge: Cambridge University Press.

Kindstrand J. F. (1990). (Red.). [Plutarchus] De Homero. Leipzig: Teubner.

Konstantinovic, I. (1989). Montaigne et Plutarque. Genève: Libraire Droz.

Müller, M. C. G. \& Kiessling, M. T. (Red.). (1821). Theodori Metochitae Miscellanea Pbilosophica et Historica. Lipsiae: F.C.G. Vogel.

Pade, M. (2007). The reception of Plutarch's Lives in fifteenth-century Italy (t. 1). Copenhagen: Museum Tusculanum Press.

Pelling, C. (2010). The liberation of Thebes in Plutarch's 'De genio Socratis' and 'Pelopidas' (s. 111-27). W: H.-G. Nesselrath (Red.). Plutarch, On the daimonion of Socrates: Human liberation, divine guidance, and philosophy. Tübingen: Mohr Siebeck.

Schamp, J. (1996). La réception de l'histoire chez Photios sous bénéfice d'inventaire (s. 9-26). W: I. Lewandowski \& L. Mrozewicz (Red.). L'image de l'antiquité chez les auteurs postérieurs. Poznań: Edition VIS.

Ševčenko, I. (1974). Society and intellectual life in the fourteenth century (s. 69-92). W: M. Berza \& E. Stânescu (Red.). XIV Congrès International des Études Byzantines, Bucarest, 6-12 septembre 1971. Bucuresti: Editura Academiei Republicii Socialiste România. 
Ševčenko, I. (1975). Theodore Metochites, the Chora, and the intellectual trends of his time (s. 19-91). W: P. A. Underwood (Red.). The Kariye Djami (t. 4: Studies in the art of the Kariye Djami and its intellectual background). London: Pantheon.

Smith, P. J. (2001). Montaigne, Plutarch and historiography (s. 167-186). W: K. Enenkel, J. L. De Jong, \& J. De Landtsheer (Red.). Recreating ancient history: Episodes from the Greek and Roman past in the arts and literature of the early modern period. Leiden: Brill.

Tartaglia, L. (1987). Il Saggio su Plutarco di Teodoro Metochita (s. 339-362). W: U. Criscuolo (Red.). Talariskos: Studia graeca Antonio Garzya sexagenario a discipulis oblata. Napoli: M. D’Auria Editore. 